\title{
Communication Strategies to Prevent Terrorist Group's Radical Ideology and Doctrine within Islamic Universities at Central Sulawesi
}

\author{
Muhammad Khairil \\ Universitas Tadulako (UNTAD) Palu \\ muh_khairil02@yahoo.com
}

\begin{abstract}
The development of terrorist groups continues to undergo metamorphosis through the transformation of the communication network and radicalism doctrine. This phenomenon makes affiliation efforts with radical groups, including building networks in the higher education. Radical Ideas easily penetrate campuses and universities. The vulnerability is not only seen from a psycho-social approach alone, but also as in instrument or media that outspread hatred and violence that designed to fit campus lifestyle. Some of the ways are such as books, magazines, bulletins, internet and social media networks. Universities can formulate appropriate and effective communication strategies as an effort in de-radicalisation, indoctrination, and de-ideologisation. Altering Islamic stigma as a terrorist religion and eliminating the image of Indonesia as implementing the teachings of Islam substantively according to Indonesian Islamic localities can do a terrorist country. Islam penetrated and developed in Indonesia not based on violence or religious radicalism, but by reflecting the spirit of Islam as the religion of blessing to the world (rahmatan lil alamin).
\end{abstract}

\begin{abstract}
Abstrak
Perkembangan kelompok teroris terus mengalami metamorfosis melalui transformasi jaringan komunikasi dan doktrin radikalisme. Penomena yang membuat upaya afiliasi dengan kelompok radikal, termasuk membangun jaringan di perguruan tinggi. Ide radikal mudah menembus kampus dan universitas. Kerentanan ini tidak hanya dilihat dari pendekatan psiko-sosial saja, tapi juga seperti pada instrumen atau media yang mengungguli kebencian dan kekerasan yang dirancang agar sesuai dengan gaya hidup kampus. Beberapa cara seperti buku, majalah, buletin, jaringan internet dan media sosial. Universitas dapat merumuskan strategi komunikasi yang tepat dan efektif sebagai upaya de-radikalisasi, indoktrinasi, dan de-ideologisasi. Mengubah stigma Islam sebagai agama teroris dan menghilangkan citra Indonesia karena menerapkan ajaran Islam secara substantif sesuai dengan lokasi Islam Indonesia dapat melakukan negara teroris. Islam ditembus dan dikembangkan di Indonesia tidak berdasarkan kekerasan atau radikalisme agama, namun dengan merefleksikan semangat Islam sebagai agama rahmatan li_al-alamin.
\end{abstract}

Keywords: Pricing, Product, Finance, Consumer, BSM 


\section{A. Introduction}

The rise of terror bombings and violent acts became a new phenomenon. The bombing target is no longer as selective, including governmental buildings, private buildings, public places, and religious locations. The casualties are children, adults, men and women alike ${ }^{1}$ People are worried and feared for their security and safety.

The radicalism has posed a real threat throughout the world, including Indonesia. Several acts of violence in the name of religion and to establish an Islamic state within the Unitary State Republic of Indonesia (NKRI) have disturbed the community and have even killed many in some cases. The events of Bali Bombing I and II, and the last act of terror, Sarinah Bombing, which is claimed to be done by some radical Islamic groups should be considered as a warning that the violent acts movements should not be underestimated. ${ }^{2}$

Central Sulawesi is considered one of the most important areas the terrorism and radicalism growth. ${ }^{3}$ The radical and terror movements and acts that took place in Central Sulawesi were substantially driven by two main reasons. First, as the excesses of communal conflicts of Poso and their widespread implications that transcended the boundaries of the time period and where the conflict occurred in Poso. Second, the radical actions that have been caused by radical terrorist network expansion into Central Sulawesi that based on Poso's conflict and outside the context of the Poso's conflict.

Terrorism study conducted by Muhammad Nur $\mathrm{Ali}^{4}$ has found three main points of the Central Sulawesi's terrorism. First, the ideological spirit that moves the terrorists is a religious dogma, therefore it appears as an extreme fundamental radical movement. Second, the amal ma'ruf nahimungkar, Islamist slogan to quell all forms of crime, carried out as the struggle obsessions, which by their interpretation is that

\footnotetext{
${ }^{1}$ Ashgar, Ali. Gerakan Terorisme Tahun 2015: Pola Serangan, Jumlah Korban dan Wajah Baru Global Jihad. Jurnal Keamanan Nasional, Volume 2 Number 1 2016. p. 4

2 Hutchison, Emma. Trauma and the Politics of Emotions: Constituting Identity, Security and Community after the Bali Bombing. International Relations, Volume 24 Number 1 March 2010. p. 65

${ }^{3}$ Nugroho, Ari Setyo. Pentingnya Komando Operasi Khusus TNI Dalam Pencegahan dan Penanggulangan Terorisme. Jurnal Defendonesia, Volume 1 Number 1 December 2013. p. 8

${ }^{4}$ Muhammad Nur Ali. Studi Terorisme di Sulawesi Tengah. Jurnal Al Ulum, Volume 16 Number 2 December 2016. p. 512
} 
power, or in this case government, is the most responsible party. Third, Poso terror act is part of the interdependent national and global terrorism networks.

Terrorism act based on radical ideas is an act of terror with the basic understanding of radicalism idea refers to Latin term "radix" which means root, base, bottom, or comprehensive, all-out and demand change hard. Radicalism idea can be divided into two levels: the level of thought and the level of activity. Firstly, as for the level of thought, the radicalism is a discourse, concepts, and ideas that are still discussed; it essentially supports violence to achieve goals. Meanwhile, in the level of action, radicalism is the socio-political and religious domain 5 .

The emergence of radical groups among society who use violence or terror in their struggle for political goals is often influenced by their relationship with the government. The dominance of the government that either by or against violence to civil society ${ }^{6}$, especially those associated with radical movements from both Muslim and non-Muslim groups, often leads to frustration and encourages them to change the way from non-violent ways to fight for their interests ${ }^{7}$.

The debate about the perpetrators and motives of terrorism often leads to the identification of ideology or religion from terrorists, because ideologies or religions are the sources of legitimacy from their actions. The government gets the legitimacy of violence or terror by its sovereignty or constitutional authority. While community groups usually get the legitimacy based on ideologies or religions that they fight for. The issue of Islamic terrorism needs to be seen and further clarified whether Islam legitimizes terror or terrorist acts either state or non-state that has hijacked Islam?

\footnotetext{
${ }^{5}$ Muhammad Khairil, dkk. Understanding terrorism based on radicalism idea in order to avoid instability for achieving environmental peace and justice the Sustainable Development Goals (SDGs). Journal of Food, Agriculture \& Environment Vol.15 (1). 2017. p.49

${ }^{6}$ Mustofa, Muhammad. Memahami Terorisme: Suatu Perspektif Kriminologi. Jurnal Kriminologi Indonesia, Volume 2 Number 3 December 2002. p. 30-38.

${ }^{7}$ Mustofa, Imam. Terorisme: Antara Aksi dan reaksi (Gerakan Islam Radikal sebagai Respon Terhadap Imperialisme Modern). RELIGIA, Volume 15 Number 1 April 2012. p. $65-87$
} 
The research results and critical studies conducted by Hendropriyono ${ }^{8}$ stated that the philosophical basis of terrorism is based on two fundamental pillars, namely ontological basis and epistemologies basis. The ontological basis of terrorism is an absolute belief (fundamental) and is the core values of all movements, strategies, and grounds of ideological justification. Ontologically, terrorism is a state of affairs that exist in the middle of society. The existence of those events always has a causal relationship between humans. That is, it is the man who causes terrorism, not the religion he believes, not the books and not the sacred texts of religions.

Furthermore, Hendropriyono stated that the epistemological foundation of the principle of justification of the fundamentalist movement to resist the Western power is the literal basis of jihad. In this epistemological region, fundamentalism's reasoning has the power of cohesion among fellow imams in the unity of resistance. As a result of Osama Bin Laden's call for terrorism, the word jihad became a new icon and keyword in the mass media, therefore, Western society, even some Indonesians, have lost in the epistemological mistake by identifying Islam, jihad, and terrorism ${ }^{9}$.

One of the main challenges that the Indonesians face regarding the development of the radical movement is the development of radical ideology within the campus environment by targeting students. In some media including CNN Indonesia, it is explained that the idea of radicalism has developed rapidly in the universities. Campus on several occasions has been used as a place of regeneration where students are instructed to follow radical ideas such as Khilafah. One informant who has been a follower of one radical organization mentions that the radical doctrine or brainwashing occurred as a freshman which then followed by military training activities. Furthermore, one of the researchers of the Indonesian Institute of Sciences (LIPI) said that radicalism has indeed touched college students through a closed and organized recruitment process, and it could potentially divide the nation. The big problem is that these groups have rigid views of beliefs and attitudes of fundamentalism, always feel the most righteous and

${ }^{8}$ A.M. Hendropriyono. TERORISME, Fundamentalis Kristen, Yahudi, Islam. Jakarta: Kompas, 2009, p. 271

${ }^{9}$ Ibid, p. 351 
have the goal of building an Islamic state which allowed to use violent means ${ }^{10}$.

Universities are places for students who have a dynamic soul to do self-actualization effort. This process of self-actualization becomes a potential target for radical groups to make efforts to disseminate a radical ideology, indoctrination and member recruitments ${ }^{11}$. The shocking fact is that most of the book bombers and Serpong bombing planners are college graduates, even among them are graduates of Islamic universities ${ }^{12}$. The perpetrator clearly demonstrates Islamic religious understanding in a narrow, exclusive, and loud fashion.

Efforts that must remain and continue to be done to prevent and solve the problem of terrorism are participatory studies, especially through communication approaches to be able to find out the more indepth process of transformation of ideological values that are believed by the terrorist group. In addition, participatory studies are to unravel and reveal the motives and forms of terror that have been done by terrorist groups so that will provide ease in the handling of acts of terrorism.

\section{B. Radical Ideology Terrorist Groups Development in Central Sulawesi}

During the reign of Suharto, or the New Order Regime, Muslims is limited and prohibited to be the identity of the political movement. Religion is considered by the ruler as a political threat to be tamed. Political elites or masses who use religious symbols to fight state hegemony have always been accused of being extreme acts, many Islamic activists are imprisoned, the religious social organization's activities are always monitored, and their activities are always intervened by the government. The political elite experienced what Zainuddin Maliki ${ }^{13}$ calls a political alienation.

10 Arifuddin. Pandangan dan Pengalaman Dosen UIN Alauddin Makassar dalam Upaya Mengantisipasi Gerakan Islam Radikal di Kalangan Mahasiswa. Jurnal Al Ulum, Volume 16 Number 2 December 2016. p. 437

11 Muqoyyidin, Andik Wahyun. Membangun Kesadaran Inklusif-Multikultural untuk Deradikalisasi Pendidikan Islam. Jurnal Pendidikan Islam Volume 2 Number 1 June 2013. p. 132

12 Detiknews. Daftar 17 Tersangka Bom Buku \& Serpong. Accessed 24 September 2017. https://news.detik.com/berita/d-1626913/-daftar-17-tersangka-bom-buku--serpong

${ }^{13}$ Zainuddin Maliki,. Agama Rakyat Agama Penguasa. Yoyakarta: Yayasan Galang. 2000. p. 89 
The downfall of Soeharto's regime in May 1998, followed by a political and economic crisis, is undoubtedly a huge stimulus to the new Islamic radical movements to proclaim their existence in general and to create a new foundation for Islamic movements in Indonesia and spreading it among the Muslims. Several prominent new groups are Laskar Jihad, Front Pembela Islam, and Angkatan Mujahidin Indonesia ${ }^{14}$.

The transition of power, marked by the downfall of the New Order government and the emergence of a Reformation era in the context of democracy, has opened up a vast space for Muslims to serve as political identities that have given rise to various struggle strategy patterns. According to Arif Afandi, ${ }^{15}$ there are at least two patterns of the struggle for the struggle of Muslims, first, Islamization of society through power. In the context of nation and state, the pattern of strategy tends to demand a prior quota in power as a reflection of a democratic country. Second, the pattern of Islamization strategies as part of the nation's political development process. This strategy pattern tends to define the Islamic struggle as a part of the struggle to create a more democratic social life.

Radicalism has been recognized by societies and religions across the world. Radicalism has been understood as situation or behaviour which is different from universal belief. Max Weber argues that radicalism as differing in one crucial aspect from the socially sanctioned outlook of common sense ${ }^{16}$. The findings show that a number of wellrecognized radical organizations within and outside Indonesia have used the Internet in their daily operation. Their reasons to use the Internet in their daily activities are included: a). Radical propaganda is able to be spread to the entire community in the world without limited by time and geographical area, b). Internet helps them to coordinate attacks online, c). Funds can be raised from the organization or individual donators across the world, d). Radical activities can be practiced anonymously, and e). Communication and interaction can be practice 24 hours a day and seven days a week. ${ }^{17}$

14 Bruinessen, Martin Van. Contemporary Developments in Indonesian Islam: Explaining the "Conservative Turn". Singapore: Institute of Southeast Asian Studies. 2013 p. 1-4.

${ }_{15}$ Arif Afandi. Islam Demokrasi Atas Bawah. Yogyakarta: Pustaka Pelajar. 1997. p. 9

16 Bittner, E. Radicalism and the Organization of Radical Movements. American Sociological Review. 1963 28(6), 928-940

${ }^{17}$ Nurdin. Radicalism on World Wide Web and Propaganda Strategy. Jurnal Al-Ulum, Volume 16 Number 2 December 2016., p. 307 
Long before the worldwide opinion on "Islamic Terrorism" surface, we have heard the term "Islamic Fundamentalism". In Arabic, "fundamentalism" or al-ushuliyyah means "fundamental or disciplined in performing religious duties". Thus, "fundamental Muslim" is a very disciplined Muslim practicing the teachings of Islam, such as praying five times in congregation and avoiding something that is obviously not halal. These "fundamental Muslims" include the Zahid, those who guard themselves and their religion and also the sufis. In this definition context, Muslims have to implement their religious teachings fundamentally. While "radicalism" in Arabic is called syiddah at-tanatu. That is, hard, exclusive, narrow-minded, rigid, and truth monopolization. Radical Muslims are narrow-minded Muslims, rigid in understanding Islam, and have an exclusive mindset in viewing other religions. ${ }^{18}$

In the year $35 \mathrm{H}$, khalifah Usman Ibn Affan was murdered fiercely by a group of extremist Muslims. This incident then recurred at the time of the khalifah Ali Ibn Abi Talib who also killed by extremists from Muslims. The extreme community, even at the very beginning of political nuance, evolved into an ideology known as Khawarij.

Fundamentalism is fundamental principles or practices. A choice of action is generally seen by contrasting sharply between the values that certain religious groups struggle for with the prevailing or established value of the order at that time. Therefore, fundamentalism is often paralleled by the term extremism, militancy, or radicalism. Historically the idea of fundamentalist politics refers to the example of two major organizations namely Al Ikhwan Al Muslimin in Egypt ${ }^{20}$ and Jamaah Al Islamiyah in Pakistan ${ }^{21}$. Both are moving towards strengthening the Muslim as their political capital and placing Islam as the ideology of its movement. Both are based on a strong political theology rooted in their ideas and attitudes as advocates of fundamentalist or radical Islamic movements.

18 Said Aqil Siroj. Tasawuf Sebagai Kritik Sosial, Bandung: Mizan dan Yayasan Ikhas. 2006, p.189

19 Aprillani Arsyad. Pandangan Agama Islam Mengenai Terorisme, Kekerasan, dan Jihad. Jurnal Ilmu Hukum Inovatif, Volume 2 Nomor 4, April 2010. p. 75

${ }^{20}$ Monier, Elizabeth Iskander and Annette Ranko. The Fall of the Muslim Brotherhood: Implication for Egypt. Middle East Policy, Volume 20 Number 4 2013. p. 111-121

${ }^{21}$ Haron, Zulkarnain and Nordin Hussin. A Study of the Salafi Jihadist Doctrine and the Interpretation of Jihad by Al Jama'ah Al Islamiyah. KEMANUSIAAN: The Asian Journal of Humanities, Volume 20 Number 2 2013. p. 15-17 
In the fundamental group's point of view, Islam is not only regulated human relationships with God alone, but also contains the doctrine of relationships among people, both in social and political aspects of the state. In such a format, Islam is typically socio-political, in which the function of religion and politics can not be separated but must be formally-legalistic in a container called "Islamic State" 22 . The terrorist movements phenomenon in Indonesia is inseparable from the presence of radical groups in Islam who feel the injustice to Muslims by the Western, especially America and its political, economic, and cultural allies. The western domination of Islamic countries is perceived as an attempt to undermine the power of Islam as a whole.

Politically, terrorism acts basically are due to the long and continuing injustices, imperialism and colonialism in the Islamic world. Therefore, theoretically, it can be said as long as the human rights abnormalities and violations are still there, reactions in the form of terrorism will still emerge. Therefore, there should be an integrated, comprehensive, and sustained effort of various elements and nations of the world based equality and equality or humanization.

Terrorism is known as a form of violence that is classified as "political violence" or also called "civil violence". According to Poltak Partogi Nainggolan ${ }^{23}$, political violence encompasses a very wide spectrum, ranging from protests or protests using violence, spontaneous and sporadic rebellions, planned and continuing rebellions, coups, insurrections, and revolutions.

Terrorism is one of many cases that has been developed in Indonesia, including various conflict areas as well as in Poso. The Terrorism case of Poso Region occurred in 2002 to 2007 or since the post-conflict reconciliation phase marked by the Malino Declaration.

The case of terrorism that occurred in Poso can be disclosed that during the conflict, Poso Muslim groups get jihad indoctrination so it gave birth to radical Muslim groups that ready to die to defend the Muslims of Poso. Post-conflict Poso, radical groups of Poso Muslims experienced a metamorphosis. Radical and terrorist groups were born

\footnotetext{
22 Azra, Azyumardi. Revisitasi Islam Politik dan Islam Kultural di Indonesia. Jurnal Indo-Islamika, Volume 1 Number 2 2012. p. 233-242

${ }^{23}$ Poltak Partogi Nainggolan. Terorisme dan Tata Dunia Baru. Jakarta: Tiga Putra Utama. 2002., p. 106
} 
post-conflict Poso who had a grudge to retaliate to Christian groups through an ideology that justified acts of terrorism.

Terrorism cases that occurred in Central Sulawesi post-conflict Poso ideologically have a fundamental difference with terrorism cases in other places or regions. The fundamental difference in the case of terrorism in Central Sulawesi is the motive behind the act of terrorism. That is revenge and the symbiotic mutualism between radical Islamic groups who deliberately came to Poso and the Muslim community of Poso who were in conflict and in need of an ideological spirit to foster the spirit of jihad the Muslim community of Poso.

The revenge that emerges among the Muslim community is caused by the Poso conflict, that has claimed lives and pillaging done to Muslim property by Christian groups. The grudges are increasingly agglomerated and exposed in acts of terror as the Muslim group feels the engineering behind the conflict resolution to protect perpetrators of Christian conflict. The assumption of the manipulation behind the conflict resolution is the non-disclosure of perpetrators of violence during the conflict that occurred since $1998 \mathrm{~s} / \mathrm{d} 2001$.

In addition to the revenge, there is a factor of symbiotic mutualism between Poso Muslim groups and radical Muslim groups who deliberately came to Poso to help Poso Muslims who, when the conflict was defeated, became victims of the conflict. The arrival of radical groups from outside Poso then inculcated a radical ideology so that the Muslim groups of Poso had an ideological spirit and an obsession with the struggle to fight Christian groups. The targets of terror acts are not solely aimed at individual Christians but are aimed at various religious symbols and security forces. The terror acts committed by Muslim groups have undergone a transformation from only battled or terrorized Christian groups into terror acts against the security forces and the general public, by shooting the security forces, armed resistance, and even robbery.

\section{Radical Ideology Outspread Within Islamic Universities}

The post-reformation era marked by the opening of democratic taps has become a fertile ground for the growth of radical Islamic groups. The phenomenon of radicalism among Muslims is often based on religious belief, even if the originator of radicalism can be born from various origins, such as economic, political, social and so on. 
The radicalism that leads to terrorism becomes an important issue for Indonesian Muslims today. These two issues have caused Islam to be labeled as a religion of terror and Muslims are considered to be fond of the holy path of violence to spread their religion. Although the assumption is easily countered, the fact that the perpetrators of terror in Indonesia are a hard-line Muslim burdened the psychology of the majority of Muslims.

Education and educational institutions are very likely to be the disseminator of the seeds of radicalism as well as the deterrent (read: deradicalization) of radical Islam. Studies on radicalism and terrorism indicate that certain Islamic educational institutions (especially non-formal ones, such as pesantren) have taught fundamentalism and radicalism to learners.

The research results conducted by Lembaga Kajian Islam dan Perdamaian (LaKIP) Jakarta is surprising. Research conducted between October 2010 to 2011 on PAI teachers and students (junior and senior high school) in Jabodetabek shows that $49 \%$ of students agree with the action of radicalism for the sake of religion. Therefore, PAI teachers have a strategic role to inculcate moderate Islam and can find the right way to tackle radical Islam. Islamic radicalism research in public schools is very important to do for several reasons ${ }^{24}$.

Not only among the middle school students, in higher education, especially in universities, are discovered that the fact that the process of radicalization was also reached the campus, especially among students. One proof is the arrest of five of Seventeen members of Pepi Fernando's network of undergraduate educators, three of whom are graduates of Sharif Hidayatullah State Islamic University (UIN) Jakarta.

Public colleges are more easily targeted for radical movement member recruitments, while religious-based colleges are considered more difficult. If it turns out that the facts show that radical movements are also rampant and fertile on religious-based campuses, Saifuddin $^{25}$ proves two things, first, there has been a change in the religious-based college and second, there has been a metamorphosis of form and movement strategy in internal radical movements.

The ideological factor is the cause of the development of radicalism among students. Theoretically, people who already have a base of

\footnotetext{
${ }^{24}$ Abu Rokhmad. Radikalisme Islam dan Upaya Deradikalisasi Paham Radikal. Jurnal Walisongo, Volume 20, Nomor 1, Mei 2012. p. 81

${ }^{25}$ Saifuddin. Radikalisme Islam di Kalangan Mahasiswa (Sebuah Metamorfosa Baru). Jurnal Analisis, Volume XI, Nomor 1, Juni 2011. p. 13
} 
student-level knowledge, when holding a radical belief, must have been through the process of mujadalah ${ }^{26}$ or exchanging opinions (debate) that are long enough and intense enough so that in the end the student can accept radical understanding.

The contact between students with Islamic radicalism is certainly not something that appears by itself. Radicalism arises because of the communication process with radical networks outside the campus. Thus, radical movements that have been there trying to make metamorphosis by recruiting students, as the educated members of their groups. This way, the impression that radicalism is simply held up by the ordinary people mostly fades on its own. This paper discusses the pattern of recruitment of students by radical groups and how their efforts in spreading Islamic radicalism on campus ${ }^{27}$.

The radicalism among students phenomenon is true and that is something that can be held and studied, even though essentially this kind of movement uses a visible system of cells, like the presence of a wind that can be felt but difficult to hold. Nevertheless, the case of Pepi Fernando's network has become a tangible proof as well as to negate that radical movements among students can already be held and studied. Students who are recruited into radical movements usually come from public or secular colleges especially those from the faculty of sciences. However, recent developments suggest that religious-based campuses are also spared the target of radical movements.

Advocates of intolerance and hate speech orators are born from taklim assembly and pengajian as the fertile ground for terrorism based on religion. An antagonistic-nativistic religious attitude, the feeling of the most righteous self, and the outer self or groups is the enemy. In effect, since they read religion in the narrow-literal spectrum, it is wrapped in radical-fundamental ideology and doctrine. Moreover, the "womb" of this group is indeed starting to develop in Indonesia which later gave birth to the radicalization of religion as a real form of resistance to the hegemony of state power.

26 Basri. Fenomena Dakwah Radikal: Penyikapan Akademisi STAIN SAS BABEL Terhadap Model dan Pendekatan dalam Berdakwah. Jurnal Mawaizh, Volume 1 Number 1 2016. p. 23-38.

${ }^{27}$ Saifuddi. Radikalisme Islam di Kalangan Mahasiswa (Sebuah Metamorfosa Baru). ANalisis: Jurnal Studi Keislaman, Volume 11 Number 1 2011. p. 17-30. 


\section{Communication Strategies to Prevent Terrorist Group's Radical Ideology and Doctrine Dissemination}

Ideology is defined as a whole set of comprehensive and systematic political, economic, social, cultural and religious ideas or beliefs. Ideology can be regarded as a comprehensive vision or as a way of looking at things. The main purpose behind an ideology is to offer a change through normative thought processes.

For people originated from Poso including students from Poso who are studying at universities especially in Central Sulawesi, directly or indirectly involved and victimized in the Poso conflict, religious doctrine with radical understanding is a great enlightenment and motivation, and thus radical groups entering Poso were welcomed and greeted with joy. As described in this research main problem that there is a symbiotic mutualism relationship between Muslim society of Poso and radical groups that had occurred since the period of communal conflict.

Understanding and interpreting religion norms and values through religious symbols such as clothing, physical characteristics (beard, turban, kopiah, etc.) to the practice of worship both mahdha' and muamalat become the way of life of Poso community since joining radical groups network outside Poso. Specifically, the understanding of the ideology of Poso radical groups is to interpret "Islam Kaffah", that is to make Islam a totality in everyday life including the enforcement of Islamic law which regulates the qisas and inflames the spirit of jihad in the effort of the Islamic Khilafah ${ }^{28}$.

The research results were done by Angel Rabasa et. al. ${ }^{29}$ provide information on the various strategies and approaches undertaken by various countries in deradicalization and counter-terrorism programs, ranging from programs that developed in the Middle East, Southeast Asia, to Europe. Especially for programs that have been implemented in Southeast Asia, the following table provides a brief overview of the deradicalization characteristics and counter-terrorism programs in four Southeast Asian countries: Singapore, Malaysia, Indonesia, and Thailand.

\footnotetext{
${ }^{28}$ Zafar. Pakistan, Terrorism and Islam. Jihat al-Islam, Volume 8 Number 2 2015. p. 34.

${ }^{29}$ Angel Rabasa et al. Deradicalizing Islamist Extremists. RAND Corporation Monograph Series. 2010. p. 120.
} 
Communication Strategies to Prevent Terrorist Group's Radical Ideology and Doctrine within Islamic Universities at Central Sulawesi

Table 1: Deradicalization and Counter-Terrorism Programs in Four ASEAN Countries $^{30}$

\begin{tabular}{|c|c|c|c|c|}
\hline Karakteristik & Singapura & Malaysia & Indonesia & Thailand \\
\hline Location & Prison & Prison & Prison & $\begin{array}{l}\text { Military } \\
\text { Camp }\end{array}$ \\
\hline Size/Amount & $\begin{array}{l}40 \text { People are } \\
\text { released }\end{array}$ & $\begin{array}{l}\text { Approx. } 100 \\
\text { people }\end{array}$ & $\begin{array}{l}\text { Approx. } \\
100 \text { people }\end{array}$ & $\begin{array}{l}1.550 \\
\text { People }\end{array}$ \\
\hline Goals & $\begin{array}{l}\text { Deradicalization } \\
\text { and counter- } \\
\text { radicalization }\end{array}$ & $\begin{array}{l}\text { Deradicalizati } \\
\text { on and } \\
\text { counter- } \\
\text { radicalization }\end{array}$ & $\begin{array}{l}\text { Intelligence } \\
\text { and counter- } \\
\text { radicalizatio } \\
\mathrm{n}\end{array}$ & $\begin{array}{l}\text { Deradicalizati } \\
\text { on and } \\
\text { counter- } \\
\text { radicalization }\end{array}$ \\
\hline Target Groups & Sub Members & Unknown & $\begin{array}{l}\text { All society } \\
\text { members }\end{array}$ & $\begin{array}{l}\text { Sub } \\
\text { Members } \\
\text { and Society }\end{array}$ \\
\hline $\begin{array}{l}\text { Mediator/Int } \\
\text { erlocator }\end{array}$ & Ulama & Ulama & $\begin{array}{l}\text { Prison } \\
\text { Officer, Ex- }\end{array}$ & Military \\
\hline $\begin{array}{l}\text { Affective } \\
\text { Components }\end{array}$ & $\begin{array}{l}\text { Psychological } \\
\text { Counseling for } \\
\text { Prisoners and } \\
\text { their families }\end{array}$ & Unknown & $\begin{array}{l}\text { Cultural } \\
\text { Interrogatio } \\
\text { n Methods, } \\
\text { Family } \\
\text { Visits }\end{array}$ & None \\
\hline $\begin{array}{l}\text { Pragmatic } \\
\text { Components }\end{array}$ & $\begin{array}{l}\text { Education, } \\
\text { Training, Jobs, } \\
\text { Family Support }\end{array}$ & $\begin{array}{l}\text { Family } \\
\text { Support }\end{array}$ & $\begin{array}{l}\text { Militant } \\
\text { and } \\
\text { Family } \\
\text { Support }\end{array}$ & $\begin{array}{l}\text { No Individual } \\
\text { Support; } \\
\text { Economic } \\
\text { Development } \\
\text { Plan }\end{array}$ \\
\hline $\begin{array}{l}\text { Ideological } \\
\text { Components }\end{array}$ & $\begin{array}{l}\text { Religious } \\
\text { Dialogue }\end{array}$ & $\begin{array}{l}\text { Religious } \\
\text { Dialogue and } \\
\text { Family } \\
\text { Counseling }\end{array}$ & $\begin{array}{l}\text { Discussion } \\
\text { with Ex- } \\
\text { Militant }\end{array}$ & $\begin{array}{l}\text { Islamic and } \\
\text { Nationalism } \\
\text { Education }\end{array}$ \\
\hline $\begin{array}{l}\text { Post } \\
\text { Programme }\end{array}$ & $\begin{array}{l}\text { Close } \\
\text { Observation, } \\
\text { Religious } \\
\text { Counseling }\end{array}$ & $\begin{array}{l}\text { Close } \\
\text { Observatio } \\
\mathrm{n}, \\
\text { Religious } \\
\text { Counseling }\end{array}$ & $\begin{array}{l}\text { Initial } \\
\text { capital } \\
\text { Assistance }\end{array}$ & None \\
\hline
\end{tabular}

${ }^{30}$ Ibid p. 120. 
Basically, the communication strategy is a blend of communication planning to achieve a set of goals. In order to achieve these objectives, the communication strategy should be able to show how operational implementation is tactically performed, in the sense that the approach may differ depending on the situation and conditions.

Arifin $^{31}$ stated that if we talk about communication strategies, that means we talk about how easy and quick a change is made to audiences. Change is the result of the inevitable communication process. All parties who communicate, inevitably must undergo changes, both small changes and major changes.

The media is actually in the midst of a social reality filled with various complex, diverse interests, conflicts, and facts. Media contents are not simply presented but it goes through the mechanism of the attraction of strong internal and external interests. What is presented in the media is not a reality but a redactional formulation work that represents reality in another's face. The medium through the formulation presents a new reality that has undergone the addition, subtraction, improvement, deletion or even distortion of the real reality.

The use of mass media by radical movements is actually not a new phenomenon, as in the event of September $11^{\text {th }}, 2001$ bring back the issue of radicalism or terrorism based on religion and it is still a controversial and central issue in the field of world security. The controversy of AlQaeda and other radical Islamic movements voicing the symbols of Islam they bring directly affects the global Muslims and influences the map of world conflict ${ }^{32}$.

Lately, the issues of Islamic radicalism re-emerged with the birth of ISIS which quickly became global topic after they uploaded a sadistic video of the murder of a US journalist on Youtube. Messages of horror are conveyed quickly and simultaneously indicate the existence of their movements. ISIS, as well as other extreme and terrorist movements, joined the mass media to attract the interest of their members who not only came from around Iraq and Syria but succeeded in attracting the

\footnotetext{
31 Anwar Arifin. Strategi Komunikasi: Suatu Pengantar Ringkas. Bandung: Armico. 1994. p. 10

32 Post, Jerrold M.. Terrorism and Right-Wing Extremism: The Changing Face of Terrorism and Political Violence in the $21^{\text {st }}$ Century: The Virtual Community of Hatred. International Journal of Group Psychoteraphy, Volume 65 Number 2 2015. p. 254.
} 
world's sympathy ${ }^{33}$. In Indonesia, this movement has been prohibited by the government, ulama, even the public themselves take precautions against the development of ISIS.

In his book, Nacos ${ }^{34}$ stated that for the past decade, global television networks have been preaching international terrorism, which on the other hand is enjoyed by terrorist groups as a form of international recognition of their existence and an opportunity to spread propaganda throughout the world. Arab satellite network Al-Jazeera, in particular, became one of the international actors in the mass media after their coverage of Afghanistan and US involvement and coalition when urging the Taliban and Al-Qaeda to get out of the country. Some Middle East television media such as AlArabiya and the Lebanese Hizbollah's al-Manar became phenomenal after the rise of Islamic radicalism and rapidly skyrocketed into one of the globally calculated local television stations.

Mass media plays a key role in deterring and informing the public on radicalism issues so that people can take precautions to the development of extremist movements starting from their own environment. Although basically, Indonesia is a moderate Islamic country and radicalism is difficult to develop in this country, but that does not mean Indonesia is not spared as a target for them, especially the younger generation. Whatever it is, the mass media has a moral and social responsibility to the public, although, on the other hand, they are indeed benefiting the movements as a form of free propaganda, but it also raises the mass movement of the people themselves to actively participate in preserving the environment of matters that could disrupt public order and security without relying solely on the government.

The role of mass media, whether it is printed or electronics (television and radio) especially in Indonesia, in counter-terrorizing radical movements that harms Muslims is indispensable. The public is entitled to get information that not only preaches negative sides, but it is expected to provide peacefulness to the society by providing positive news about Islam because a religion is revealed to the earth is for the salvation of humanity itself and not the religion of violence. Mass media

${ }^{33}$ Greene, Kyle J.. ISIS: Trends in Terrorist Media and Propaganda. International Studies Capstone Research Papers. 3. 2015.

http://digitalcommons.cedarville.edu/international_studies_capstones/3

${ }^{34}$ Nacos, Brigitte L. (2007) Mass-Mediated Terrorism, The Central Role of The Media in Terrorism and Counterterrorism. Rowman \& Littlefield Publisher, Inc. 
need to be more proactive and objective in doing the news, therefore it is no longer considered a tool of propaganda. Petrus Reinhard Golose ${ }^{35}$ describes the role of the media in the process of radicalization as well as the radical counter media as follows:

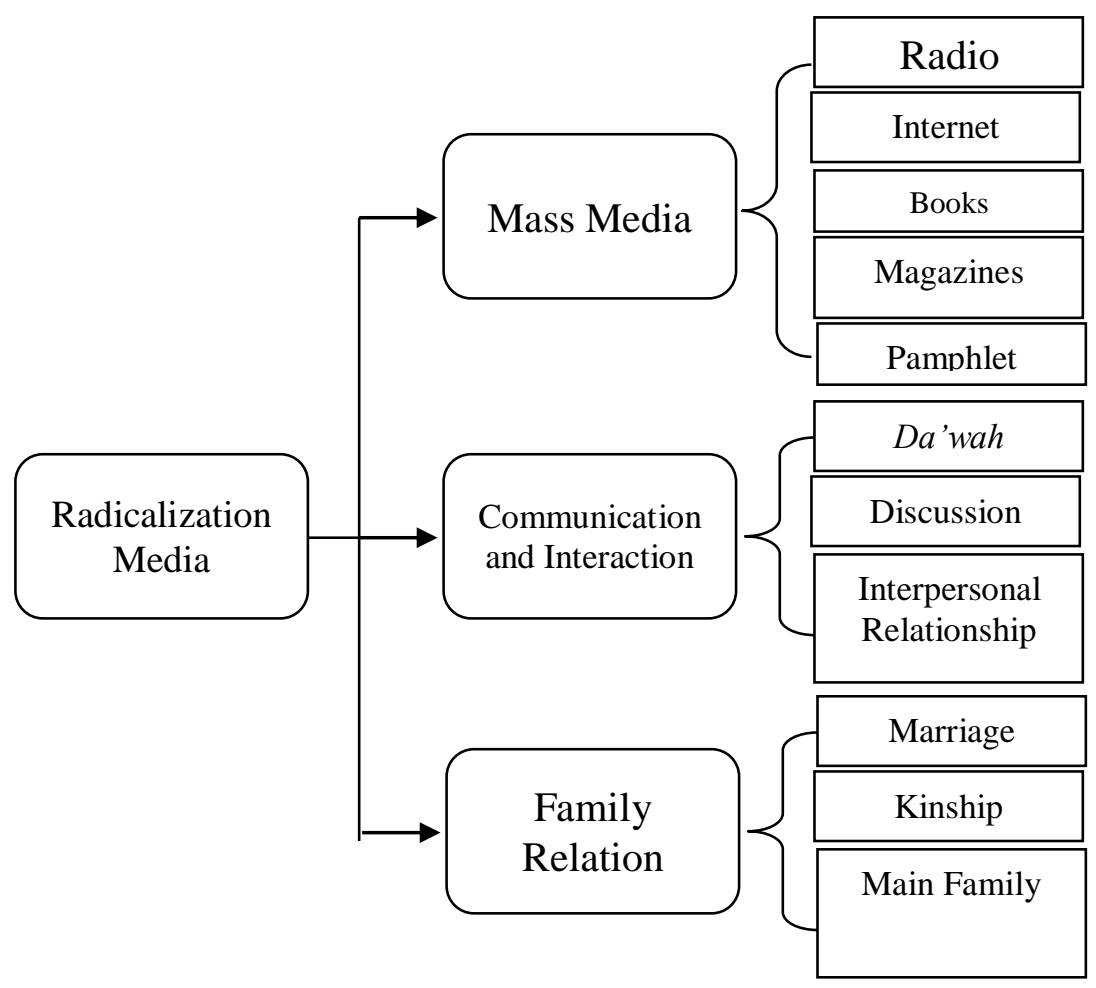

Source : Adapted from Petrus, 2009

Communication that occurs when a person access mass media is a one-way communication. This resulted in no direct interaction between the communicator and the communicant. The information conveyed by the communicator through the mass media makes the reader in a passive position. This means that the reader can not reject the social reality built by the media. In fact, the reality built by the media is not necessarily in accordance with the actual social reality.

In radicalism and terrorism context, the media constructs a reality that differs from the social reality of everyday life. United Nations Office

${ }^{35}$ Petrus Reinhard Golose. 2009. Deradikalisasi Terorisme. Jakarta:YPKIK. 
on Drug and Crime (UNODC) ${ }^{36}$ stated that the goal of terrorism propaganda that spread across the mass media is to promote violence, promoting the rhetoric of extremists who support violence, recruitment, sedition, and radicalization.

The rise of radicalism and terrorism propaganda through the internet cannot be defeated only by using legal approach. Countering the propaganda of radicalism and terrorism through internet requires the role of all circles within society by doing media literacy movement. Media literacy emphasizes one's ability to think critically and allows the person to make decisions related to the selected media program and how to interpret information received from the mass media. Intelligent media is the ability of the public to be aware of the content that is on the internet media. People are expected not to receive all the information spread through the internet media. The public is expected to continue to question critically both the content and the validity of the source information obtained. So the truth contained in the media is not necessarily regarded as the social reality itself.

Mass media coverage of terrorism basically to ensure public access to the information and protect fundamental freedoms as well as, to prevent violence and combat terrorism in need future. On top of that, the mass media provide information to the public; therefore, it is a responsibility of every journalist to meet the standards and the norms of journalism that has been set, so that people will get the right and accurate information. By covering information on terrorism, in a way, will provide answers for handling terrorism in order to ensure peace and justice. In this manner, as the result will promote peaceful and inclusive societies for sustainable development, provide access to justice for all and build effective, accountable and inclusive institutions at all levels ${ }^{37}$.

The debate about the perpetrators and motives of terrorism often leads to the identification of the ideology or religion of the terrorists, since religious ideology is a source of legitimacy from its action. The state gets the legitimacy of violence or terror because of its sovereignty

\footnotetext{
${ }^{36}$ Benedicta Dian Ariska Candra Sari. Literacy Media In The Counter Of Radicalism Propaganda And Terrorism Through Internet Media. Jurnal Peperangan Asimetrik, Volume 3, Number 1, Year 2017. p.19

${ }^{37}$ Muhammad Khairil dkk. Mass Media Coverage on Terrorism in Order to Achieve Peace and Justice According to the World Agenda of Sustainable Development Goals (SDGs). 2017. Journal of INFORMATION Volume 20, Number 7 (A), pp. 4938
} 
or constitutional authority. While community groups usually get the legitimacy of ideology or religion that wants to fight for. The issue of "Islamic terrorism" needs to be seen and further clarified whether Islam legitimizes terror or terrorist acts either state or non-state that has hijacked Islam?

It is ironic when the act of terrorism handling leads to slander, accusations after accusations against the ideology, beliefs, and adherents of a particular religion. It needs a thorough and procedural investigation that is true according to applicable law, then the execution is done after who have been convicted as terrorists are being sentenced. Similarly, when the mass medias provide information to the audience, they must meet the standards and rules of journalism that have been established so that people obtain correct and accurate information. Critical thinking and profound analysis become the benchmark for the creation of a society that is tolerant of pluralism, upholds democracy and respects every human right to its humanity.

\section{E. Conclusion}

Radical Ideology existence and development, especially through terrorist groups, becomes very strategic steps especially in universities to influence students as recruitment efforts for membership. Therefore, the role of universities in preventing the radical development of terrorist groups in Central Sulawesi becomes crucial as counter-radicalism efforts. One of the critical things in preventing the spread of radical ideology in universities is through communication strategy which is done by, first, an approach through mass media especially strengthening the ability to build media literacy awareness. Second, through social relations, especially interpersonal and persuasive communication skills in building religious awareness with the spirit of religious pluralism. Third, an interactive and argumentative scientificologist based on true references to Islamic values as an academic foundation so as not to be easily instigated and influenced by the pattern of radical ideological doctrine and recruitment of terrorist groups. 


\section{Bibliography}

Afandi, Arif. Islam Demokrasi Atas Bawah. Yogyakarta: Pustaka Pelajar. 1997. p. 9

Ali, Muhammad Nur. Studi Terorisme di Sulawesi Tengah. Jurnal Al Ulum, Volume 16 Number 2 December 2016. p. 512

Arifin, Anwar. Strategi Komunikasi: Suatu Pengantar Ringkas. Bandung: Armico. 1994. p. 10

Arifuddin. Pandangan dan Pengalaman Dosen UIN Alauddin Makassar dalam Upaya Mengantisipasi Gerakan Islam Radikal di Kalangan Mahasiswa. Jurnal Al Ulum, Volume 16 Number 2 December 2016. p. 437

Arsyad, Aprillani. Pandangan Agama Islam Mengenai Terorisme, Kekerasan, dan Jihad. Jurnal Ilmu Hukum Inovatif, Volume 2 Nomor 4, April 2010. p. 75

Ashgar, Ali. Gerakan Terorisme Tahun 2015: Pola Serangan, Jumlah Korban dan Wajah Baru Global Jihad. Jurnal Keamanan Nasional, Volume 2 Number 1 2016. p. 4

Azra, Azyumardi. Revisitasi Islam Politik dan Islam Kultural di Indonesia. Jurnal Indo-Islamika, Volume 1 Number 2 2012. p. 233-242

Basri. Fenomena Dakwah Radikal: Penyikapan Akademisi STAIN SAS BABEL Terhadap Model dan Pendekatan dalam Berdakwah. Jurnal Mawaizh, Volume 1 Number 1 2016. p. 23-38.

Bittner, E. Radicalism and the Organization of Radical Movements. American Sociological Review. 1963 28(6), 928-940

Bruinessen, Martin Van. Contemporary Developments in Indonesian Islam: Explaining the "Conservative Turn". Singapore: Institute of Southeast Asian Studies. 2013 p. 1-4.

Detiknews. Daftar 17 Tersangka Bom Buku \& Serpong. Accessed 24 September 2017. https://news.detik.com/berita/d-1626913/-daftar17-tersangka-bom-buku--serpong

Golose, Petrus Reinhard. 2009. Deradikalisasi Terorisme. Jakarta:YPKIK.

Greene, Kyle J.. ISIS: Trends in Terrorist Media and Propaganda. International Studies Capstone Research Papers. 3. 2015. http://digitalcommons.cedarville.edu/international_studies_capsto nes/3 
Haron, Zulkarnain and Nordin Hussin. A Study of the Salafi Jihadist Doctrine and the Interpretation of Jihad by Al Jama'ah Al Islamiyah. KEMANUSIAAN: The Asian Journal of Humanities, Volume 20 Number 2 2013. p. 15-17

Hendropriyono, A.M.. TERORISME, Fundamentalis Kristen, Yahudi, Islam. Jakarta: Kompas, 2009, p. 271

Hutchison, Emma. Trauma and the Politics of Emotions: Constituting Identity, Security and Community after the Bali Bombing. International Relations, Volume 24 Number 1 March 2010. p. 65

Khairil, Muhammad, dkk. Mass Media Coverage on Terrorism in Order to Achieve Peace and Justice According to the World Agenda of Sustainable Development Goals (SDGs). 2017. Journal of INFORMATION Volume 20, Number 7 (A), pp. 4938

Khairil, Muhammad, Understanding terrorism based on radicalism idea in order to avoid instability for achieving environmental peace and justice the Sustainable Development Goals (SDGs). Journal of Food, Agriculture \& Environment Vol.15 (1). 2017. p.49

Maliki, Zainuddin. Agama Rakyat Agama Penguasa. Yoyakarta: Yayasan Galang. 2000. p. 89

Monier, Elizabeth Iskander and Annette Ranko. The Fall of the Muslim Brotherhood: Implication for Egypt. Middle East Policy, Volume 20 Number 4 2013. p. 111-121

Muqoyyidin, Andik Wahyun. Membangun Kesadaran InklusifMultikultural untuk Deradikalisasi Pendidikan Islam. Jurnal Pendidikan Islam Volume 2 Number 1 June 2013. p. 132

Mustofa, Imam. Terorisme: Antara Aksi dan reaksi (Gerakan Islam Radikal sebagai Respon Terhadap Imperialisme Modern). RELIGIA, Volume 15 Number 1 April 2012. p. 65-87

Mustofa, Muhammad. Memahami Terorisme: Suatu Perspektif Kriminologi. Jurnal Kriminologi Indonesia, Volume 2 Number 3 December 2002. p. 30-38.

Nacos, Brigitte L. (2007) Mass-Mediated Terrorism, The Central Role of The Media in Terrorism and Counterterrorism. Rowman \& Littlefield Publisher, Inc.

Nainggolan, Poltak Partogi. Terorisme dan Tata Dunia Baru. Jakarta: Tiga Putra Utama. 2002., p. 106

Nugroho, Ari Setyo. Pentingnya Komando Operasi Khusus TNI Dalam Pencegahan dan Penanggulangan Terorisme. Jurnal Defendonesia, Volume 1 Number 1 December 2013. p.8 
Nurdin. Radicalism on World Wide Web and Propaganda Strategy. Jurnal Al-Ulum, Volume 16 Number 2 December 2016., p. 307

Post, Jerrold M.. Terrorism and Right-Wing Extremism: The Changing Face of Terrorism and Political Violence in the $21^{\text {st }}$ Century: The Virtual Community of Hatred. International Journal of Group Psychoteraphy, Volume 65 Number 2 2015. p. 254.

Rabasa, Angel, et al. Deradicalizing Islamist Extremists. RAND Corporation Monograph Series. 2010. p. 120.

Rokhmad, Abu. Radikalisme Islam dan Upaya Deradikalisasi Paham Radikal. Jurnal Walisongo, Volume 20, Nomor 1, Mei 2012. p. 81 Saifuddi. Radikalisme Islam di Kalangan Mahasiswa (Sebuah Metamorfosa Baru). ANalisis: Jurnal Studi Keislaman, Volume 11 Number 1 2011. p. 17-30.

Saifuddin. Radikalisme Islam di Kalangan Mahasiswa (Sebuah Metamorfosa Baru). Jurnal Analisis, Volume XI, Nomor 1, Juni 2011. p. 13

Sari, Benedicta Dian Ariska Candra. Literacy Media In The Counter Of Radicalism Propaganda And Terrorism Through Internet Media. Jurnal Peperangan Asimetrik, Volume 3, Number 1, Year 2017. p.19

Siroj, Said Aqil. Tasawuf Sebagai Kritik Sosial, Bandung: Mizan dan Yayasan Ikhas. 2006, p.189

Zafar. Pakistan, Terrorism and Islam. Jihat al-Islam, Volume 8 Number 2 2015. p. 34. 